\title{
Combined multiple gene genealogies and phenotypic characters differentiate several species previously identified as Botryosphaeria dothidea
}

\author{
Bernard Slippers ${ }^{1}$ \\ Department of Microbiology and Plant Pathology, \\ Forestry and Agricultural Biotechnology Institute, \\ University of Pretoria, South Africa
}

Pedro W. Crous

Centraalbureau voor Schimmelcultures, Uppsalalaan 8, 3584 CT Utrecht, Netherlands

Sandra Denman

Department of Plant Pathology, University of Stellenbosch, Stellenbosch 7602, South Africa

Teresa A. Coutinho

Brenda D. Wingfield

Michael J. Wingfield

Department of Microbiology and Plant Pathology and Department of Genetics, Forestry and Agricultural Biotechnology Institute, University of Pretoria, South Africa

\begin{abstract}
Botryosphaeria dothidea is one of the most commonly reported species in a genus of important pathogens of woody plants. This taxon generally is accepted to represent a species complex, and hence its identity remains unclear. Previous studies either have treated $B$. dothidea as the valid name for $B$. ribis and $B$. berengeriana or argued for them to be separate entities. To add to the confusion, no ex-type cultures are available for either $B$. dothidea or B. ribis. The aim of the present study, therefore, was to recollect and characterize these fungi and designate a set of reference cultures that can be used in future studies. To this end, morphological, cultural and multi-allelic DNA sequence datasets from the rDNA (ITS 1, 5.8S, and ITS 2), $\beta$-tubulin and EF1- $\alpha$ genes were used to fully characterize these species. Botryosphaeria dothidea was found to be distinct from $B$. ribis, while $B$. berengeriana was retained as synonym of the former name. Furthermore, Fusicoccum aesculi is accepted as anamorph of $B$. dothidea, while the anamorph of $B$. ribis is newly described as $F$. ribis sp. nov. Botryosphaer$i$ a ribis could be distinguished from $B$. parva based on $\beta$-tubulin and EF1- $\alpha$ sequence data. A combined phylogeny of the three gene regions used in this study also showed that the genus Botryosphaeria rep-
\end{abstract}

Accepted for publication May 23, 2003.

${ }^{1}$ Corresponding author. E-mail: bernard.slippers@fabi.up.ac.za resents two distinct phylogenetic assemblages that correspond to species with Diplodia and Fusicoccum anamorphs.

Key words: Botryosphaeria, epitypification, Fusicoccum, key, phylogeny, systematics

\section{INTRODUCTION}

Botryosphaeria Ces. \& De Not. was described in 1863 (Cesati and De Notaris 1863). Cesati and De Notaris (1863) first included 12 species in the genus but did not provide detailed morphological descriptions of the species. De Notaris (1863) added another four species, including $B$. berengeriana De Not., for which he provided detailed descriptions and sketches. Saccardo (1877) amended the initial generic descriptions of Cesati and De Notaris to exclude hypocreaceous species, which he transferred to two new genera, Gibberella and Lisea. Von Arx and Müller (1954, 1975), who did an extensive revision and key (respectively) of the genus, cite this amendment as part of the generic description.

Cesati and De Notaris (1863) did not select a type species for the genus. Barr (1972) rejected proposals that either B. quercuum (Schwein.) Sacc. or B. berengeriana be designated as the lectotype species of the genus because these species were not part of the original description of the genus. Barr (1972) therefore designated B. dothidea (Moug. : Fr.) Ces. \& De Not. (= Sphaeria dothidea Moug. : Fr.), one of the species originally included by Cesati and De Notaris (1863), as the lectotype species of the genus.

Despite obvious similarities between specimens, early researchers tended to describe new Botryosphaeria species, where these fungi occurred on different hosts (Cesati and De Notaris 1863, De Notaris 1863, Saccardo 1877, 1882, Grossenbacher and Duggar 1911, Putterill 1919, Trotter 1928). Von Arx and Müller (1954), however, synonymized many of these species under B. quercuum and B. dothidea, based on teleomorph herbarium material. Many researchers did not accept the extensive synonymies of von Arx and Müller (1954). For example, B. dothidea and $B$. ribis Grossenb. \& Duggar have been viewed as distinct species by many due to differences in anamorph morphology (Punithalingam and Holliday 1973, MorganJones and White 1987, Rayachhetry et al 1996, Smith 
and Stanosz 2001, Zhou and Stanosz 2001a, b), while others treated them as synonyms sensu von Arx and Müller (Witcher and Clayton 1963, Barr 1972, English et al 1975, Spiers 1977, Maas and Uecker 1984, Pennycook and Samuels 1985, Brown and Britton 1986, Smith et al 1994). A further basis for confusion is that von Arx and Müller (1975) considered B. berengeriana, which they had synonymized earlier with B. dothidea (von Arx and Müller 1954), as one of the most common species of the genus. According to von Arx (1987), the name B. dothidea should be restricted to isolates pathogenic to roses, while he considered $B$. berengeriana (including B. ribis) as polyphagous. The name $B$. berengeriana is not commonly used currently, except in Japan (Sassa et al 1998, Ogata et al 2000).

The Botryosphaeria teleomorph is seldom seen in culture, whereas the anamorphs are common. Species differences are manifested in the anamorph, while there is considerable overlapping in the continuous characters of the teleomorph, such as spore sizes. For these reasons, anamorph characters often are considered important to identify species in this genus (Shoemaker 1964, Pennycook and Samuels 1985). Denman et al (2000) recorded 18 anamorph genera that have been linked to Botryosphaeria, with Botryodiplodia (Sacc.) Sacc., Diplodia Fr., Dothiorella Sacc., Fusicoccum Cda., Lasiodiplodia Ellis \& Everh. and $M a-$ crophoma (Sacc.) Berl. \& Voglino the most common. Of these, Macrophoma has been synonymized with Sphaeropsis Sacc. (Sutton 1980). Crous and Palm (1999) also showed that Botryodiplodia is a nomen dubium and that the type specimen of Dothiorella is best accommodated in Diplodia. The use of anamorph characters also is complicated by the overlapping characteristics between species and the effect of aging on conidium morphology (Pennycook and Samuels 1985, Jacobs and Rehner 1998, Smith and Stanosz 2001).

Phylogenetic studies, using both morphological and molecular data, have contributed significantly to Botryosphaeria taxonomy. Recent studies have used a combination of morphological and DNA sequence, RAPD or ISSR data to study relations among species and to define Botryosphaeria spp. (Jacobs and Rehner 1998, Denman et al 1999, Smith et al 2001, Smith and Stanosz 2001, Zhou et al 2001, Zhou and Stanosz 2001a). One of the main conclusions drawn from these studies is that Botryosphaeria spp. can be separated into two groups, namely those with dark-conidial diplodia-like anamorphs and those with hyalineconidial fusicoccum-like anamorphs. Denman et al (2000) revised the generic taxonomy of the anamorphs that have been linked to Botryosphaeria and concluded that those with hyaline conidia should be included in Fusicoccum and those with conidia that are dark and opaque when mature should be included in Diplodia. These findings were supported by Zhou and Stanosz (2001a), who referred the two anamorph genera to section Hyala and section Brunnea. Contrary to these studies, Zhou and Stanosz (2001b) found that these groups were not supported by partial mitochondrial (mt) SSU sequence data. These authors suggested that these contradictions might have been due to lack of resolution using this part the mitochondrial rDNA gene region or that it might have arisen through hybridization or horizontal gene transfer before the separation of the two groups mentioned above.

Despite their considerable contribution to Botryosphaeria taxonomy, single gene phylogenies and other molecular data have not resolved some long-standing taxonomic controversies. The morphological species B. dothidea is paraphyletic and divided into two clades based on molecular data (Jacobs and Rehner 1998, Denman et al 1999, 2000, Smith et al 2001, Smith and Stanosz 2001, Zhou et al 2001, Zhou and Stanosz 2001a, b). These clades are regarded in some of the above studies as representing $B$. dothidea and $B$. ribis, raising a question regarding their synonymy. Furthermore, while rDNA sequence data and RAPD marker data could not distinguish $B$. parva Pennycook \& Samuels and B. ribis (Smith and Stanosz 2001, Zhou and Stanosz 2001a), ISSR markers showed that they were distinct (Zhou et al 2001).

It is evident that the commonly encountered and economically important genus Botryosphaeria remains in taxonomic disarray. The objective of our study is to test morphologically based hypotheses with data derived from multiple gene sequences. The need to use multiple gene phylogenies to distinguish closely related species has been emphasized before (O'Donnell and Cigelnik 1997, Taylor et al 2000). For this reason, rRNA (spanning the internal transcribed spacer region one [ITS 1], 5.8S gene and ITS 2 regions) sequence data were used in this study together with data from the partial $\beta$-tubulin and translation elongation factor $1-\alpha(E F 1-\alpha)$ gene sequences to determine the phylogenetic relationships of $B$. dothidea, B. ribis and B. parva.

\section{MATERIALS AND METHODS}

Isolates and type material.-Thirty-one isolates representing nine Botryosphaeria spp. were used in this study (TABLE I). In an attempt to obtain representative specimens and isolates of $B$. dothidea, fresh material was collected from southern Switzerland and northern Italy in Oct 2000. This is the same time of year, area and included the same hosts upon which Cesati and De Notaris based the original descriptions. 
SLIPPERS ET AL: BOTRYOSPHAERIA CHARACTERIZATION

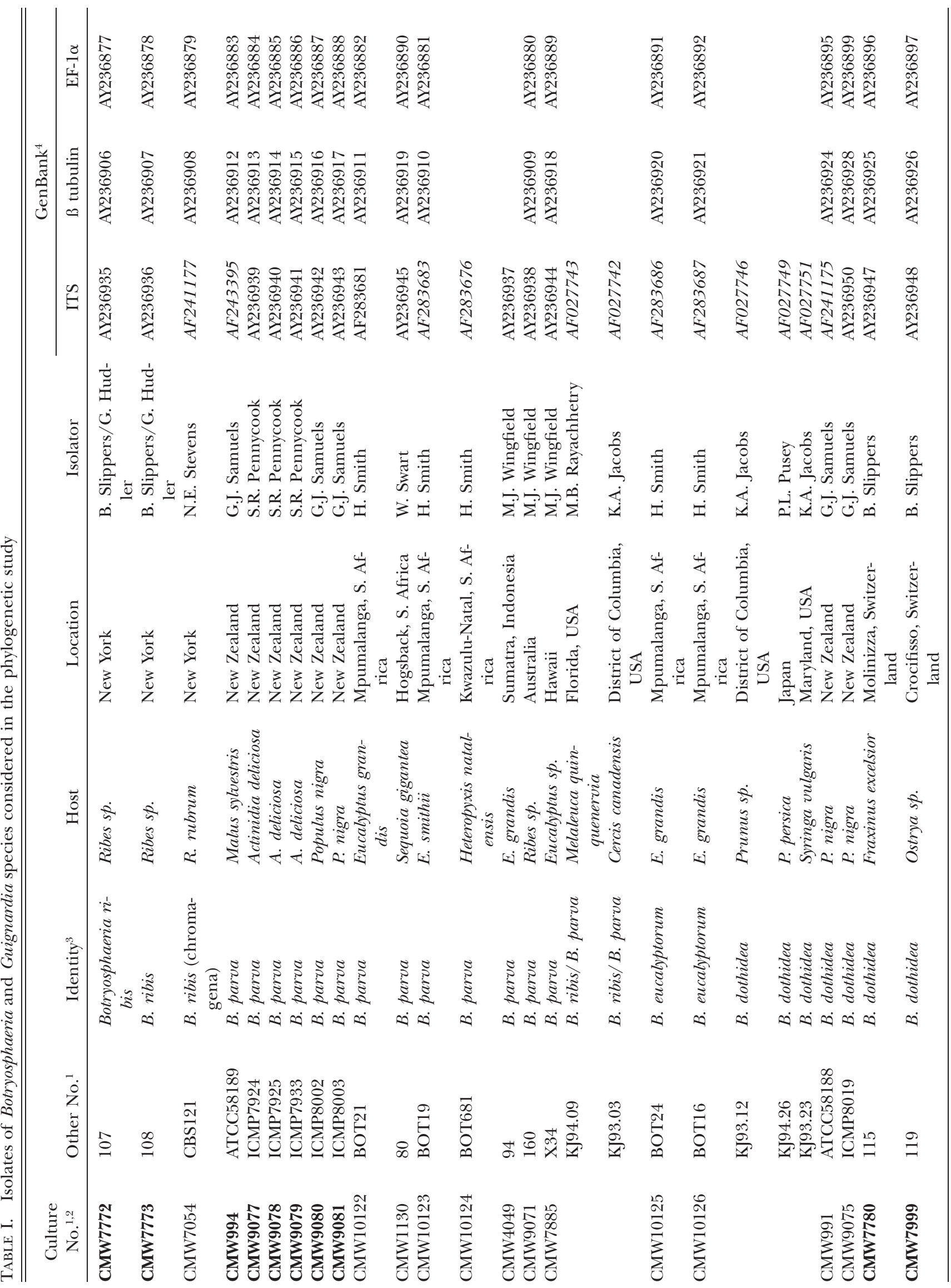




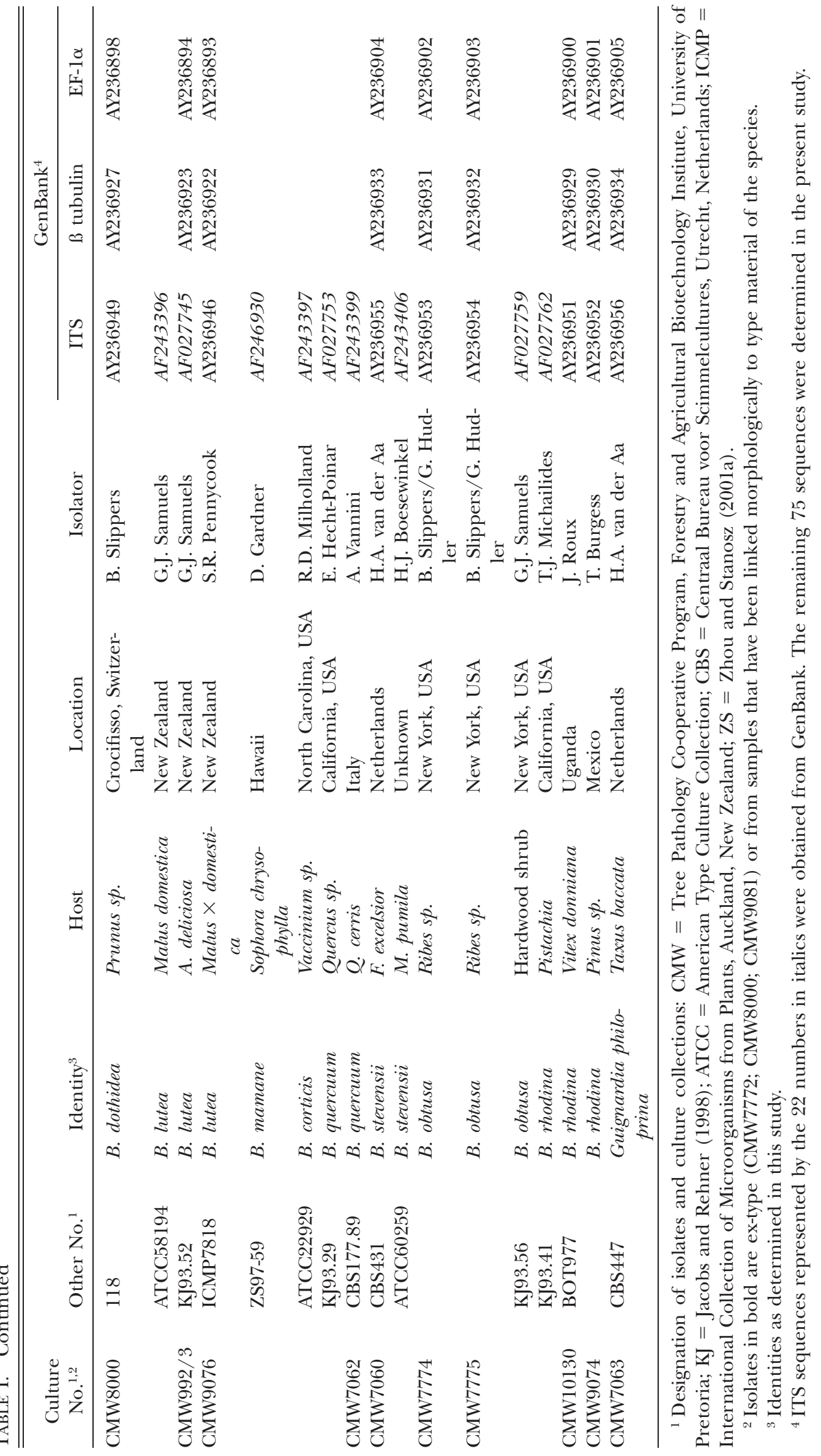


Isolations were made from ascomata or pycnidia on dead or dying twigs of various hardwood species (TABLE I). Isolations similarly were made from twigs of Ribes spp. showing symptoms of cane dieback from Ithaca, New York. This is the host genus and area from which the original material for the description of $B$. ribis was collected by Grossenbacher and Duggar. Ex-type isolates of $B$. parva Pennycook \& Samuels were obtained from the International Collection of Microorganisms from Plants (ICMP), Landcare Research New Zealand Ltd., Auckland, New Zealand. Other isolates of representative Botryosphaeria spp. were obtained from the Centraalbureau voor Schimmelcultures (CBS), Utrecht, Netherlands and the Culture Collection of the Tree Pathology Co-operative Programme (CMW), FABI, University of Pretoria, South Africa (TABLE I). Botryosphaeria dothidea, $B$. ribis and B. parva were compared based on morphological and molecular data. Other common Botryosphaeria spp. were used only in molecular comparisons.

Initial identification of the isolates was achieved based on conidial morphology. Isolates were grown on $2 \%$ water agar (WA; Biolab agar, Midrand, Johannesburg, S.A.) with sterilized pine needles, or halved twigs of Malus sp., Eucalyptus sp. or Populus sp. as substratum, at $25 \mathrm{C}$ under near-UV light, to induce sporulation. Cultures were maintained on malt- and yeast-extract agar (MYA; 2\% malt extract, $0.2 \%$ yeast extract and $1.5 \%$ agar; Biolab, Midrand, Johannesburg, S.A.) at $25 \mathrm{C}$ and stored on this medium at 4 C. Colony morphology, color (Rayner 1970), and growth rates between 10 and $30 \mathrm{C}$, were determined on potato-dextrose agar (PDA; $0.4 \%$ potato extract, $2 \%$ dextrose, $1.5 \%$ agar, Biolab, Midrand, Johannesburg, S.A.).

Type material or other representative specimens and cultures of B. dothidea, B. ribis, B. parva and B. berengeriana were obtained from various herbaria, including CUP, PDD, $\mathrm{RO}, \mathrm{S}$. Ascomata or pycnidia were mounted in lactophenol. Sections of speciments, freshly collected and in vitro ascomata and pycnidia, were cut with an American Optical Freezing Microtome or by hand. Morphological observations and measurements were made with a light microscope, an Axiocam digital camera and accompanying software (Carl Zeiss, Germany).

DNA isolation and amplification.-A modification of the phenol:chloroform DNA extraction method of Raeder and Broda (1985) was used to isolate DNA from the fungal isolates as described in Smith et al (2001). The primers ITS1 (5' TCCGTAGGTGAACCTGCGG 3') and ITS4 (5' TCCT CCGCTTATTGATATGC $3^{\prime}$ ) (White et al 1990) were used to amplify part of the nuclear rRNA operon in PCR reactions. The amplified region included the $3^{\prime}$ end of the $16 \mathrm{~S}$ (small subunit) rRNA gene, the first internal transcribed spacer (ITS1), the complete 5.8S rRNA gene, the second ITS (ITS2) and the $5^{\prime}$ end of the $26 \mathrm{~S}$ (large subunit) rRNA gene. A part of the $\beta$-tubulin gene region was amplified by use of the primers Bt2a (5' GGTAACCAAATCGGTGCTG CTTTC $3^{\prime}$ ) and Bt2b (5' ACCCTCAGTGTAGTGACCCTT GGC 3') (Glass and Donaldson 1995). Amplification of part of the EF1- $\alpha$ was done with the primers EF1-728F (5' CATCGAGAAGTTCGAGAAGG) and EF1-986R (5' TACTTGAAGGAACCCTTACC) (Carbone et al 1999). PCR reac- tion mixtures contained final concentrations of: 2.5 units Taq DNA polymerase (Roche Molecular Biochemicals, Almeda, California), $1 \times$ buffer and $\mathrm{MgCl}_{2}$ mixture $(10 \mathrm{mM}$ Tris-HCL, $1.5 \mathrm{mM} \mathrm{MgCl}$, $50 \mathrm{mM} \mathrm{KCl}$ ), $0.2 \mathrm{mM}$ of each $\mathrm{dNTP}$ and $0.15 \mu \mathrm{M}$ of each primer and made up to a final volume of $50 \mu \mathrm{L}$ with water. During the PCR reaction, the DNA first was denatured at $94 \mathrm{C}$ for $2 \mathrm{~min}$, followed by 40 cycles of denaturation ( $94 \mathrm{C}$ for $30 \mathrm{~s}$ ), annealing ( $55 \mathrm{C}$ for $45 \mathrm{~s}$ ) and elongation (72 C for $1 \frac{1 / 2}{2} \mathrm{~min}$ ) and ended with a final elongation step at $72 \mathrm{C}$ for $5 \mathrm{~min}$. Amplification of the EF1- $\alpha$ region was problematic for some species. In these cases amplifications were done by replacing the Taq polymerase with Expand High Fidelity Taq polymerase (Roche Molecular Biochemicals, Almeda, California) with the same reaction concentrations as above and PCR cycle conditions as indicated by the supplier. PCR amplicons were electrophoresed on $1 \%$ agarose gels, stained with ethidium bromide and visualized under UV illumination. Size estimates were made using $100 \mathrm{bp}$ or $\lambda$ standard size markers.

DNA sequencing and analysis.-PCR products were cleaned using High Pure PCR Product Purification Kit (Roche Molecular Biochemicals, Almeda, California). Both strands of the amplicons were sequenced using the same primers that were used for the initial amplification. Reactions were performed using the ABI PRISM Big Dye Terminator Cycle Sequencing Ready Reaction Kit (Perkin-Elmer Applied BioSystems, Foster City, California) as indicated by the manufacturer and run on an ABI PRISM 377 autosequencer (Perkin-Elmer Applied BioSystems, Foster City, California).

To compare B. dothidea, B. ribis, B. parva and other Botryosphaeria isolates used in this study, with those from previous studies, 22 ITS rDNA sequences from GenBank were included in the analyses (TABLE I) (Jacobs and Rehner 1998, Smith et al 2001, Smith and Stanosz 2001, Zhou and Stanosz 2001a). BLAST searches were used to find any other related sequences from GenBank, not referred to in these studies. Trees were rooted to sequence data of an isolate of Guignardia philoprina (Berk. \& M.A. Curtis) Aa, which was previously described in the genus Botryosphaeria before it was placed in the closely related genus, Guignardia Viala \& Ravaz. Despite the close relationship between these last named genera, unambiguous alignment of outgroup sequence with that of the ingroup was not possible for all parts of intron and ITS regions.

ITS rDNA sequence data were analyzed using Sequence Navigator version 1.0.1 (Perkin Elmer Applied Biosystems, Foster City, California) and manually aligned by inserting gaps. Phylogenetic analyses based on parsimony were done using PAUP (Phylogenetic Analysis Using Parsimony) version 4.0b8 (Swofford 1999). Gaps were treated as a fifth character, and all characters were unordered and of equal weight. Maximum-parsimonious trees were found using heuristic searches and including only informative characters in stepwise (random) addition and tree bisection and reconstruction (TBR) as branch swapping algorithm. Maxtrees were unlimited, branches of zero length were collapsed and all multiple equally parsimonious trees were saved. Branch supports, using 1000 bootstrap replicates (Felsenstein 1985), and estimated levels of homoplasy and 
phylogenetic signal (retention and consistency indices and g1-value) (Hillis and Huelsenbeck 1992) also were determined in PAUP. Decay analyses of the branch nodes were determined using Autodecay (Eriksson 1998). Phylogenetic hypotheses also were tested using distance analyses with the neighbor-joining algorithm and an uncorrected p-factor in PAUP.

Statistical congruence between the ITS rDNA, $\beta$-tubulin and EF1- $\alpha$ sequence datasets was tested using partition homogeneity tests (Farris et al 1995, Huelsenbeck et al 1996) in PAUP. These tests revealed that the data were combinable. The datasets subsequently were analyzed together. Repetitive minisatellite regions in the intron of the EF1- $\alpha$ were coded to represent a single, rather than multiple, evolutionary events.

\section{RESULTS}

Morphological characteristics and typification.-The published description of $S$. dothidea (Fries 1823) refers to a fungus from fallen twigs of a Fraxinus sp. However, the herbarium specimen of S. dothidea in the Fries collection, collected by Mougeot, which has been cited as the type material (von Arx and Müller 1954), contains a sample with thorns that appears to be Rosa sp. This sample, thus, cannot be the holotype. No type specimen of $S$. dothidea on Fraxinus by Mougeot could be located in other herbaria that might have such a collection (BM, BR, K, LILLE, LIP, NCY, STR). Given that the holotype could not be located, the only remaining $S$. dothidea sample in the Fries herbarium is designated here as the neotype representing $B$. dothidea. This material, however, is not definitive of the species because the specimens are immature and contain no spores.

To clarify taxonomic confusion surrounding $B$. dothidea, this taxon is epitypified here. An epitype is designated to complement the neotype and other authentic specimens, as well as their descriptions, which represent $B$. dothidea. The epitype also allowed isolation of cultures. To find an epitype, three samples were collected during our study from a nearby locality (the border between Switzerland and Italy) to that of some of the collections of Cesati and De Notaris (TABLE II). The specimens were collected from Fraxinus sp., Prunus sp. and Ostrya sp. These samples contained ascomata that conformed to descriptions of B. dothidea by Fries (1823) and Cesati and De Notaris (1863). Thus, one of these samples (PREM57372 on Prunus sp.) is designated as the epitype specimen.

A taxonomic description of B. dothidea (FIGS. 1-7) based on the epitype material and cultures made from it, is given below. Cultures obtained from these samples produced an anamorph that matches de- scriptions of $F$. aesculi Corda by Pennycook and Samuels (1985) and Crous and Palm (1999).

A specimen labeled as $B$. berengeriana was obtained from the collection of De Notaris (RO). This specimen carries the signature of De Notaris and is from the same host (Rhamnus frangula) referred to in the original description (De Notaris 1863). It is likely that this is the material used by De Notaris for that description, or at least is similar to it. Ascomata on this material, as well as the original description of $B$. berengeriana, were not distinguishable from those of the neotype or epitype specimens of B. dothidea (TABLE II).

Grossenbacher and Duggar (1911) described, but did not typify, Botryosphaeria ribis. Three collections used by Grossenbacher and Duggar for this description were located in CUP. We have designated one of these as lectotype for $B$. ribis. This material of $B$. ribis is mature and well preserved and provides ample substance to characterize this species. This lectotype of $B$. ribis also contains a well-developed and preserved anamorph.

Specimens of Ribes sp. canes with dieback, which were collected on our behalf from the same geographical area as the original type material (New York, U.S.A.), contained pycnidia of a Fusicoccum sp. and a Diplodia sp. The former species corresponds to the anamorph on the type material and to the original description of an anamorph associated with B. ribis. Isolates from this Fusicoccum sp. were used in cultural, morphological and molecular studies. In this paper, a description of B. ribis and its anamorph, based on this material and the lectotype specimens, is given to accompany the molecular characterization of this taxon (FIGS. 8-14).

Isolates residing in the clades that represent $B$. dothidea and $B$. ribis have similar ascomata, ascospores, conidial morphology and cultural characteristics. However, these species can be distinguished from each other using average dimensions of these features, especially in culture (taxonomic description, key, Figs. 1-14).

Both the type and corresponding ex-type cultures for $B$. parva are well preserved and representative of the description of this taxon. Using this material, $B$. parva and B. dothidea, as described here, clearly were distinguishable based on morphological features (key). There is no consistent morphological distinction between $B$. ribis and B. parva, other than some variation in septation in discharged and aged spores (key, FIGS. 8-15) (TABLE III).

Phylogenetic sequence analyses.-The ITS dataset consisted of 563 characters after alignment; 418 uninformative characters were excluded, and 145 parsimony- 
SLIPPERS ET AL: BOTRYOSPHAERIA CHARACTERIZATION

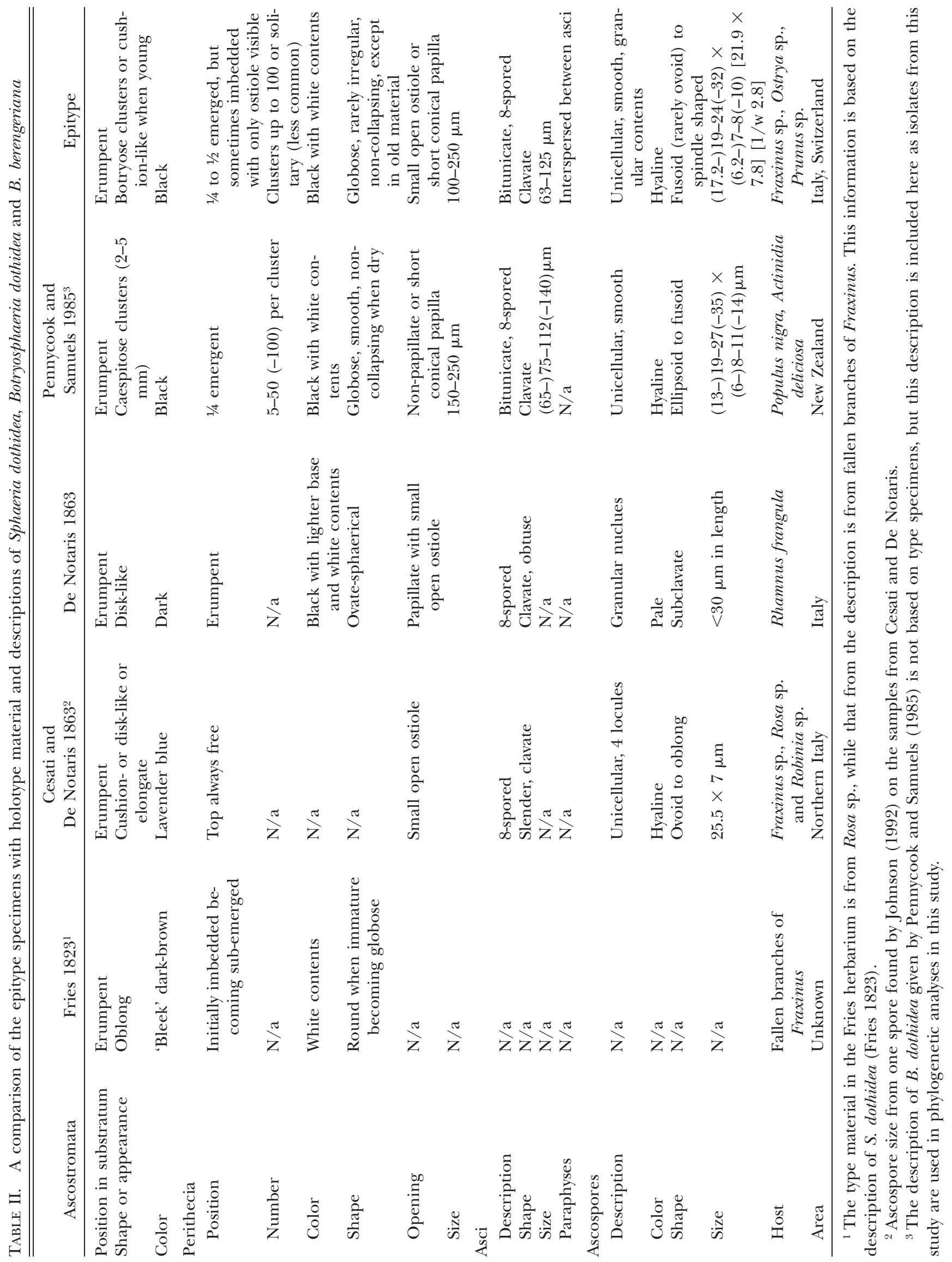



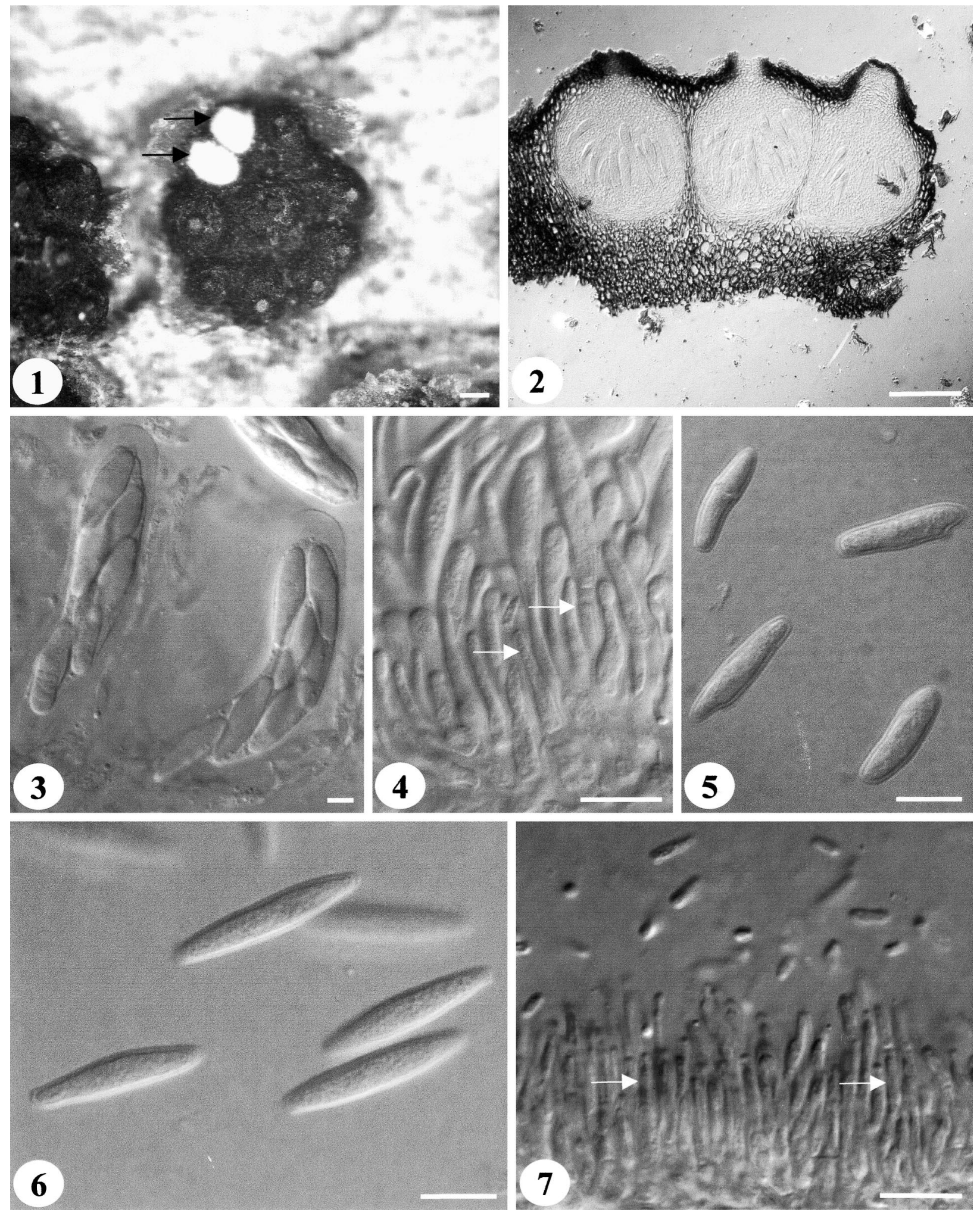

FIGS. 1-7. Botryosphaeria dothidea, dissecting microscope and DIC light-microscope micrographs. 1. Botryose ascomata, from which the tops of two have been removed to show the typical white centrum contents (arrows). 2. Median, longitudinal section through a mature ascoma. Bars $=100 \mu \mathrm{m}$. 3. Asci and ascospores. 4. Conidiogenous cells (arrows). 5. Conidia from nature. 6. Conidia produced in culture on WA and pine needles. 7. Spermatiophores (arrows) and spermatia. Bars $=10$ $\mu \mathrm{m}$. 

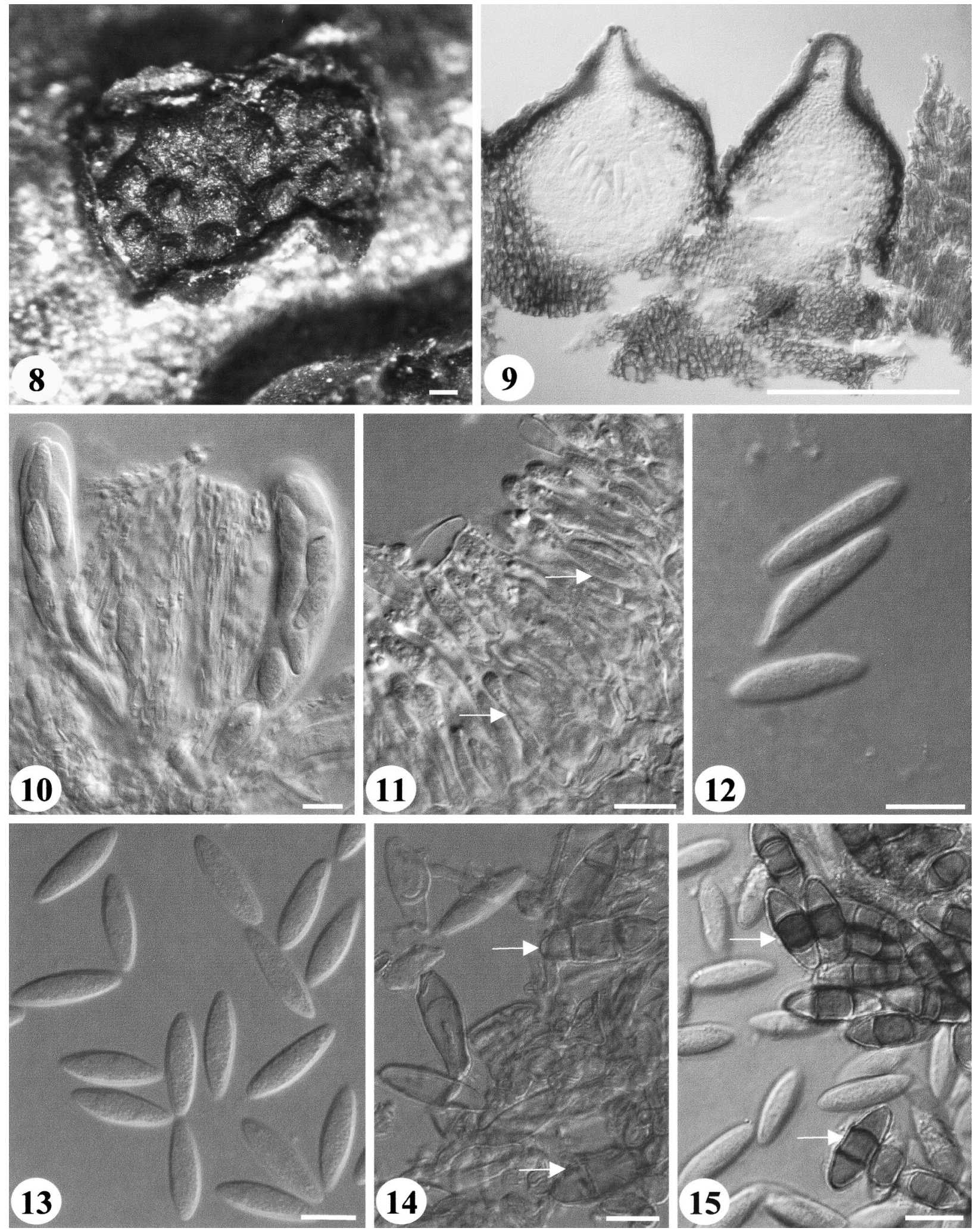

FIGS. 8-14. Botryosphaeria ribis, dissecting microscope and DIC light-microscope micrographs. 8, 9. Ascomata. Bars $=100$ $\mu \mathrm{m}$. 10. Asci and ascospores. 11. Conidiogenous cells. 12. Conidia from nature. 13, 14. Conidia produced in culture on WA and pine needles; older conidia septate (arrows). Bars $=10 \mu \mathrm{m}$.

FIG. 15. B. parva, DIC light-microscope micrograph. Conidia produced in culture on WA and pine needles; older conidia septate (arrows). Bar $=10 \mu \mathrm{m}$. 
TABLE III. A comparison of the holotype material and descriptions of Botryosphaeria ribis (Grossenbacher and Duggar 1911) and B. parva (Pennycook and Samuels 1985) ${ }^{1}$

\begin{tabular}{|c|c|c|}
\hline & B. ribis & B. parva \\
\hline \multicolumn{3}{|l|}{ Ascostromata } \\
\hline Position in substrate & Erumpent & Erumpent \\
\hline Shape or appearance & Botryose clusters (1-4 mm) & Caespitose clusters $(2-5 \mathrm{~mm})$ \\
\hline \multicolumn{3}{|l|}{ Ascomata } \\
\hline Position & $\begin{array}{l}1 / 3 \text { emergent, but sometimes sub- } \\
\text { merged or wholly emerged }\end{array}$ & $1 / 4$ emergent \\
\hline Number & $\mathrm{N} / \mathrm{a}$ & $5-50(-100)$ per cluster \\
\hline Color & Black with white contents & Black with white contents \\
\hline Shape & $\begin{array}{l}\text { Round when immature becoming glo- } \\
\text { bose }\end{array}$ & Globose, smooth, non-collapsing when dry \\
\hline Opening & Papillate ostiole & Non-papillate or short conical papilla \\
\hline Size & $175-250 \mu \mathrm{m}$ & $150-250 \mu \mathrm{m}$ \\
\hline \multicolumn{3}{|l|}{ Asci } \\
\hline Description & $\mathrm{N} / \mathrm{a}$ & Bitunicate, 8-spored \\
\hline Shape & Clavate & Clavate \\
\hline Size & $80-120 \times 17-20 \mu \mathrm{m}$ & $75-143(-210) \mu \mathrm{m}$ \\
\hline Paraphyses & Filiform interspersed between asci & \\
\hline \multicolumn{3}{|l|}{ Ascospores } \\
\hline Description & Unicellular & Unicellular, smooth \\
\hline Color & Hyaline & Hyaline \\
\hline Shape & Fusoid & Broadly ellipsoid to fusoid \\
\hline Size & $\begin{array}{l}(14-) 18-22(-27) \times 6-8(-10)[20.5 \times \\
7.1] \mu \mathrm{m}[1 / \mathrm{w} 2.9]\end{array}$ & $\begin{array}{l}(14-) 18-23(-26) \times(7-) 8-10(-11)[20.8 \times \\
9.2 \mu \mathrm{m}][1 / \mathrm{w}=2.2]\end{array}$ \\
\hline \multicolumn{3}{|l|}{ Anamorph } \\
\hline General & Same stroma as teleomorph & Same stroma as teleomorph \\
\hline Pycnidia (on material) & $\begin{array}{l}\text { Same as ascomata or depressed globular } \\
\text { and imbedded }\end{array}$ & Same as given for ascomata \\
\hline Pycnidia (in culture) & $\mathrm{N} / \mathrm{a}$ & $\begin{array}{l}\text { Globose, non-papillate, single or aggregate } \\
\text { (up to } 0.5 \mathrm{~mm} \text { diam) }\end{array}$ \\
\hline Conidia & $\begin{array}{l}\text { Fusoid to ellipsoid, obtuse apex and flat } \\
\text { base, unicellular, hyaline, rarely be- } \\
\text { coming light brown with 1-2 septa }\end{array}$ & $\begin{array}{l}\text { Ellipsoid with obtuse apex and flat base, uni- } \\
\text { cellular, hyaline, becoming light brown } \\
\text { with } 1-2 \text { septa with age, middle section of- } \\
\text { ten darker brown }\end{array}$ \\
\hline Conidial size (in vivo) & $\begin{array}{l}(16-) 19-22(-24) \times 5-6(-7)[20.8 \times \\
5.5] \mu \mathrm{m}[1 / \mathrm{w} 3.8]\end{array}$ & $\mathrm{N} / \mathrm{a}$ \\
\hline Conidial size (in vitro) & $\begin{array}{l}(15-) 16-19(-20) \times 5-6(-7)[17.2 \times \\
5.5] \mu \mathrm{m}[1 / \mathrm{w} 3.1]\end{array}$ & $\begin{array}{l}(12-) 15-19(-24) \times 4-6[16.9 \times 5.4] \mu \mathrm{m}[1 / \\
\quad \mathrm{w}=3.1]\end{array}$ \\
\hline Host & Ribes spp. & $\begin{array}{l}\text { Populus nigra, Malus } \times \text { domestica, Actinidia } \\
\text { deliciosa, Sequoia sp., Eucalyptus spp., Ribes } \\
\text { sp. }\end{array}$ \\
\hline Geographic region & New York, USA & $\begin{array}{l}\text { Australia, New Zealand, Hawaii, South Africa } \\
\text { Sumatra }\end{array}$ \\
\hline
\end{tabular}

${ }^{1}$ All information is as given in the original description and was confirmed during the current study and left unchanged, except ascospore and conidial measurements, host and area, which are given as determined in this study.

informative characters were used in the analyses. These data contained significant phylogenetic signal $(P<0.01$; $11=-0.644)$ (Hillis and Huelsenbeck 1992). After heuristic searches in PAUP, 71 most-parsimonious trees of 325 steps were retained $(\mathrm{CI}=$ 0.757 ; RI $=0.933)$ (FIG. 16).
A partition homogeneity test of the full dataset, combining ITS-rDNA, $\beta$-tubulin and EF1- $\alpha$, indicated that the datasets could be combined ( $P$ value $=$ $0.32)$. The combined dataset consisted of 1344 characters after alignment (TreeBASE S861, M1396). A total of 968 characters were excluded, including 954 


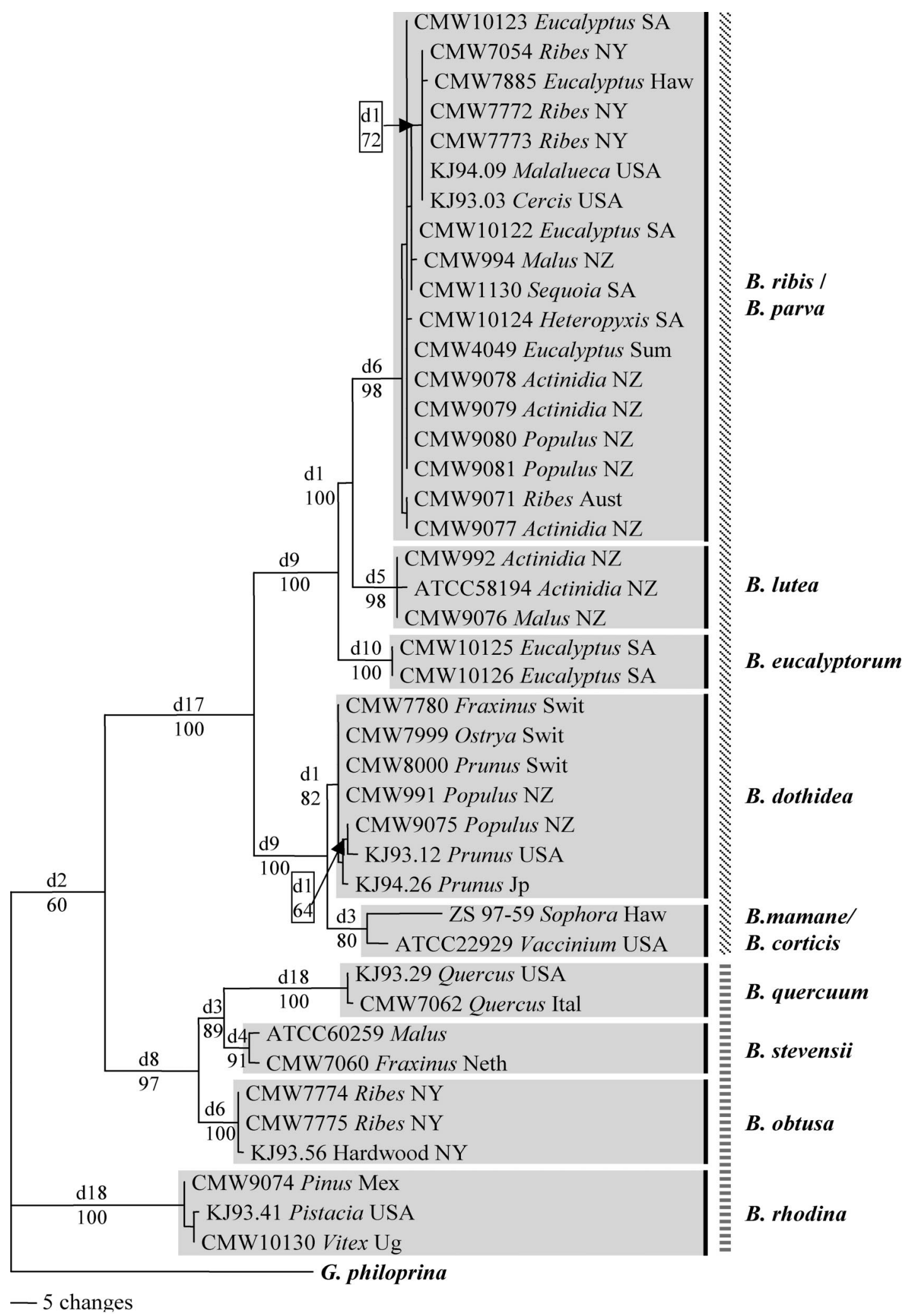

FIG. 16. Most-parsimonious tree of 325 steps obtained from ITS1, 5.8S and ITS2 rDNA sequence data. Branch supports are indicated by decay indices above the nodes and bootstrap values (1000 replicates) below the nodes. The tree is rooted to the outgroup Guignardia philoprina. Clades are shaded individually and their identities are as used in this study. Host and origin (Aust $=$ Australia, Haw $=$ Hawaii, Ital $=$ Italy, Jp = Japan, Neth $=$ Netherlands, NY $=$ New York, NZ = New Zealand, Mex = Mexico, SA = South Africa, Sum = Sumatra, Swit $=$ Switzerland, Ug = Uganda), of each isolate also are indicated. $\mathrm{\Omega}=$ Botryosphaeria spp. with Fusicoccum anamorphs and $\Xi=$ Botryosphaeria spp. with Diplodia anamorphs. 
uninformative characters and 14 minisatellite characters from the EF1- $\alpha$ intron region that were coded to represent one evolutionary event. Using the 390 parsimony-informative characters (significant phylogenetic signal $[<0.01 ; \mathrm{g} 1=-0.851]$ [Hillis and Huelsenbeck 1992]), 10 most-parsimonious trees of 858 steps were retained after heuristic searches in PAUP $(\mathrm{CI}=0.795$; RI $=0.91)($ FIG. 17$)$.

For both datasets, the same clades were identified by parsimony and distance analyses. The analyses of both datasets showed that the branch supports separating the main clades, which are identified as $B$. $l u$ tea Phillips, B. eucalyptorum Crous, H. Smith \& M.J. Wingf., B. dothidea, B. quercuum, B. stevensii Shoemaker, B. obtusa (Schw.) Shoemaker and B. rhodina (Cooke) von Arx, were well supported (>d4/91\% bootstrap) (Figs. 16, 17). ITS rDNA sequences of $B$. mamane Gardner and B. corticis (Demaree \& Wilcox) von Arx \& Müller are significantly distinct but were related more closely to each other than to any other species used in the analysis. These two species grouped in a sister clade to B. dothidea. Botryosphaer$i a$ ribis and $B$. parva could not be distinguished based on ITS rDNA data (FIG. 16), but were clearly separated in the combined datasets (FIG. 17).

Botryosphaeria spp. were divided into two main clades in the combined dataset. These correspond to the fusicoccum-like and diplodia-like anamorph types, respectively (FIG. 17). In the clade with Fusicoccum conidia, B. dothidea was clearly distinct, with the strongest support (d53/100\% bootstrap in analyses of combined datasets) of all the clades. Similarly, among Botryosphaeria spp. with Diplodia anamorphs, the distinction of B. rhodina was supported strongly (d63/100\% bootstrap). Botryosphaeria rhodina did not group with other isolates having Diplodia anamorphs in the rDNA dataset when using parsimony, but the branch separating these taxa was weakly supported (d2/60\% bootstrap) (FIG. 16). Distance analysis of this rDNA dataset (tree not shown), however, also placed this species among other Botryosphaeria spp. with dark-spored (Diplodia) anamorphs, as we found in the analysis of the combined dataset.

\section{TAXONOMY}

There are a number of published descriptions pertaining to the type material and other authentic specimens of $B$. dothidea, B. ribis and their anamorphs (Fries 1823, Cesati and De Notaris 1863, De Notaris 1863, Winter 1886, Saccardo 1877, Grossenbacher and Duggar 1911, von Arx and Müller 1954, Punithalingam and Holliday 1973, Sutton 1980, Pennycook and Samuels 1985, Crous and Palm 1999). Due to the confusion regarding the use of these names in the descriptions, revised descriptions based on the type material and fresh collections made as part of this study are provided here. The morphological description of $B$. parva, which also is considered in this study, is not repeated here because this would be redundant and would not add substantially to the original description provided by Pennycook and Samuels (1985).

Botryosphaeria dothidea (Moug. : Fr.) Ces. \& De Not., Comment. Soc. Crittog. Ital. 1:212. 1863.

Figs. 1-7

= Sphaeria dothidea Moug. : Fr. in Fries, Syst. Mycol. 2: 423. 1823.

= Botryosphaeria berengeriana De Not., Sfer. Ital. 82. 1863[1864].

Anamorph. Fusicoccum aesculi Corda in Sturm, Deutschl. Fl., Abth. 3, 2:111. 1829.

Ascostroma erumpent through the bark, 200-500 $\mu \mathrm{m}$ diam. Ascomata pseudothecial, forming a botryose aggregate of up to 100 , sometimes solitary, globose with a central ostiole, $1 / 4$ to $1 / 2$ emergent, rarely imbedded, papilate or not, brown to black; pseudothecial wall comprising 5-15 layers of textura angularis, outer region of dark brown or brown cells, inner region of 2-4 layers of hyaline cells lining the locule. Asci bitunicate, clavate, $63-125 \times 16-20 \mu \mathrm{m}$, 8spored, between numerous filiform, septate, rarely branched toward the tip, pseudoparaphyses, 2-4 $\mu \mathrm{m}$ wide. Ascospores fusoid to ovoid, sometimes with tapered ends giving a spindle shaped appearance, (17-) 19-24(-32) $\times(6-) 7-8(-10) \mu \mathrm{m}$ (average of 102 ascospores $22.7 \times 7.8 \mu \mathrm{m}, 1 / \mathrm{w} 2.9)$, unicellular, hyaline, smooth with granular contents, biseriate in the ascus. Conidiomata pycnidial in nature (anamorph structures were present only on the sample from $O s$ trya sp.), morphologically indistinguishable from the ascomata. Conidia narrowly fusiform, or irregularly fusiform, base subtruncate to bluntly rounded, (17-) $18-20(-22) \times 4-5 \mu \mathrm{m}$ (average of 35 conidia $19.6 \times$ $4.8 \mu \mathrm{m}, 1 / \mathrm{w} 4.1)$, hyaline, unicellular, rarely forming a septum before germination, smooth with granular contents. Conidiogenous cells holoblastic, hyaline, subcylindrical, $6-20 \times 2-5 \mu \mathrm{m}$, proliferating percurrently with 1-2 proliferations and periclinical thickening. Spermatia unicellular, hyaline, allantoid to rodshaped, 3-6 × 1.5-2 $\mu \mathrm{m}$. Spermatophores hyaline, cylindrical to subcylindrical, $4-10 \times 1-2 \mu \mathrm{m}$.

Cultural characteristics. Colonies olivaceous buff $\left(21^{\prime \prime \prime} \mathrm{d}\right)$, becoming olivaceous gray $\left(21^{\prime \prime \prime \prime \prime} \mathrm{i}\right)$ to violaceous black $\left(65^{\prime \prime \prime \prime} \mathrm{k}\right)$, with a sparse to moderately dense, appressed mycelial mat, occasional columns of aerial mycelium reaching the lid, margin smooth appearing crenulate as the colony darkens with age. Optimum temperature for growth $25(-30)$ C, colony 


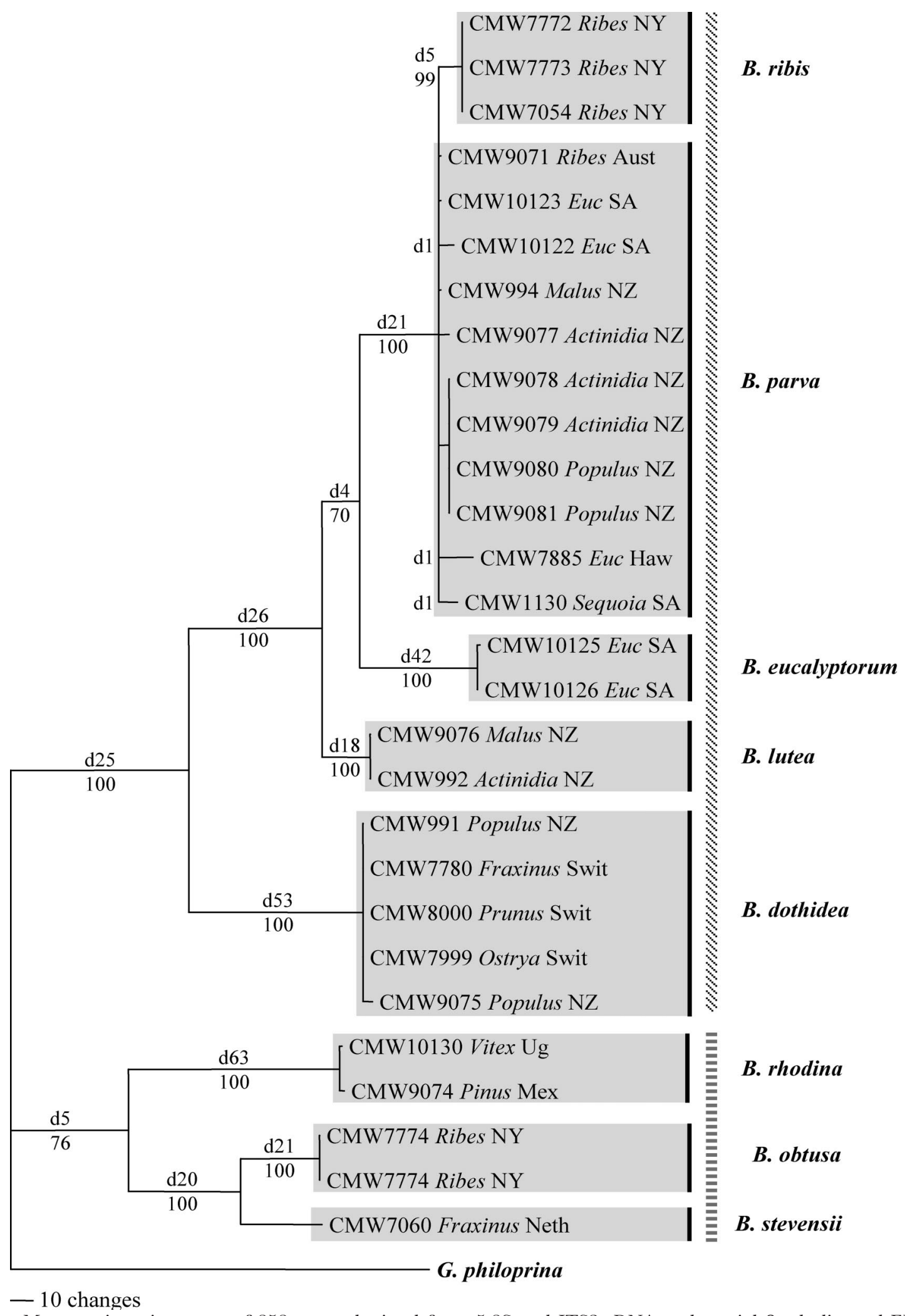

FIG. 17. Most-parsimonious tree of 858 steps obtained from 5.8S and ITS2 rDNA and partial $\beta$-tubulin and EF1- $\alpha$ gene sequence data. Support for the branching points are given in decay values above the nodes and bootstrap values (1000 replicates) below the nodes. The tree is rooted to outgroup Guignardia philoprina. Clades are shaded individually and their identities are as used in this study. Isolate identities are given in this order: number, host and origin (Aust = Australia, Haw $=$ Hawaii, Neth $=$ Netherlands, NY $=$ New York, USA, NZ = New Zealand, Mex = Mexico, SA = South Africa, Swit $=$ Switzerland, Ug = Uganda). $\mathbf{\Omega}=$ Botryosphaeria spp. with Fusicoccum anamorphs and $\Xi=$ Botryosphaeria spp. with Diplodia anamorphs. 
reaching $50 \mathrm{~mm}$ radius on PDA after $4 \mathrm{~d}$ at $25 \mathrm{C}$ in the dark. Pycnidia (formed on WA on sterilized twigs of Malus sp., Eucalyptus sp., Populus sp. or needles of Pinus sp. within 7-14 d) superficial, globose, mostly solitary and covered by mycelium. Conidia produced in culture similar to those formed in nature, but regularly shaped, longer and appearing more narrowly fusiform, (20-)23-27(-30) $\times 4-5(6) \mu \mathrm{m}$ (average of 102 conidia $24.7 \times 4.9 \mu \mathrm{m}, \mathrm{l} / \mathrm{w} 5$ ).

Specimens examined. FRANCE. Rosa sp., 1823, Fries ex Mougeot (NEOTYPE designated here, Sphaeria dothidea, herbarium S). SWITZERLAND. TICINO: Crocifisso, Prunus sp., Oct 2000, B. Slippers (EPITYPE designated here, PREM57372, culture CMW8000); Ostrya sp., Oct 2000, $B$. Slippers (PREM57373, culture CMW7999); Molinizza, Fraxinus sp., Oct 2000, B. Slippers (PREM57374, culture CMW7780). ITALY. Pusiano, Populus sp., 31 Oct 1846, Cesati et De Notaris; Pusiano, Fraxinus sp., 1846, Cesati et De Notaris; Locality unknown, Rhamnus frangula, 1863, De Notaris. GERMANY. Pr. Jever, Fraxinus sp., Koch ex Cesati et De Notaris (Rabenhorst. Herb. Mycol. 750, herbarium RO); Pr. Dreisen, Robinia pseudoacacia, Lasch ex Cesati et De Notaris (Rabenhorst. Herb. Mycol. 1330, RO).

Botryosphaeria ribis Grossenb. \& Duggar, Tech. Bull. N.Y. Agric. Exp. St. 18:128. $1911 . \quad$ FIgS. 8-14

Anamorph. Fusicoccum ribis Slippers, Crous, M.J. Wingf., sp. nov.

Ascomata aggregata 5-50-ni, pseudoperitheciales, botryosa, globosa ostiolo centrali, papillata vel non, brunnea vel nigra, 175-250 $\mu \mathrm{m}$, pariete pseudothecii 5-15 stratis texturae angularis composita, stratis exterioribus atrobrunneis vel nigris, cum 2-4 stratis cellularum hyalinarum cavitatem saepientibus. Pycnidia in stromate eisdem quibus ascomatis, et illis simillimis, vel singularia, in surculis juvenibus hospitis inclusa. Conidia unicellularia, fusiformia, interdum irregulariter fusiformia, basin subtruncata vel obtuse rotundata, hyalina, granularia, superficiebus levibus, raro cum aetate septata, (16-) 19-23(-24) × 5-6(-7) $\mu \mathrm{m}$. Cellulae conidiogenae holoblasticae, hyalinae, subcylindricae, 6-22 × 2-5 $\mu \mathrm{m}$, percurrenter cum 12 proliferationibus prolificentes. Pycnidia (in vitro in WA in surculis sterilifactis specierum generum Mali, Eucalypti Populi que, vel foliis Pini intra dies 7-14 facta) superficialia, globosa, plerumque solitaria vel bini ad quaterni aggregata mycelio tecta. Conidia a fructificationibus istis, illis in vivo factis similia sed breviora, late fusiformia vel ovoidea, forma regulariores, semel vel bis septata, aetate pallide brunnea, post emissionem (15-) 16-20 × 5-6(-7) $\mu \mathrm{m}$.

Ascostroma erumpent through the bark, pulvinate, $100-400 \mu \mathrm{m}$ in diam. Ascomata pseudothecial, forming botryose aggregate of 5-50, globose with central ostiole, papilate or not, brown to black, 175-250 $\mu \mathrm{m}$, pseudothecial wall comprising 5-15 layers of textura angularis, outer region of dark brown or brown cells, inner region 2-4 layers of hyaline cells lining the locule. Asci bitunicate, clavate, $80-120 \times 17-20 \mu \mathrm{m}$, 8spored, between numerous filiform, septate, rarely branched and then toward the tip, pseudoparaphyses, 2-4 $\mu \mathrm{m}$ wide. Ascospores fusoid to ellipsoid, often round at the ends then broadly ellipsoidal, (14-)18$23(27) \times 6-8(-10) \mu \mathrm{m}$ (average of 80 ascospores $20.5 \times 7.1 \mu \mathrm{m}, 1 / \mathrm{w} 2.9)$, hyaline, unicellular, smooth with granular contents, biseriate in the ascus. Pycnid$i a$ in same stromata as ascomata and morphologically indistinguishable from them, or solitary and imbedded in young host shoots. Conidia fusiform, sometimes irregularly fusiform, base subtruncate to blunt, (16-) 19-23(-24) × 5-6(-7) $\mu \mathrm{m}$ (average of 90 conidia $20.8 \times 5.5 \mu \mathrm{m}, 1 / \mathrm{w} 3.8)$, hyaline, unicellular, rarely septate with age, smooth with granular contents. Conidiogenous cells holoblastic, hyaline, subcylindrical, $6-22 \times 2-5 \mu \mathrm{m}$, proliferating percurrently with 1-2 proliferations with periclinical thickening. Spermatia not seen.

Cultural characteristics. Colonies white to olivaceous buff $\left(21^{\prime \prime \prime} \mathrm{d}\right)$, becoming olivaceous gray $\left(21^{\prime \prime \prime \prime \prime} \mathrm{I}\right)$ to violaceous black $\left(65^{\prime \prime \prime \prime} \mathrm{k}\right)$, sectors often becoming rapidly darker and remaining darker than the rest of the culture, with very thick, felty mycelial mat from the surface to the lid, and smooth margin, but those of darker sections appearing lacinate. Optimum temperature for growth $25 \mathrm{C}$, colony reaching $65 \mathrm{~mm}$ radius on PDA after $4 \mathrm{~d}$ at $25 \mathrm{C}$ in the dark. Pycnidia (formed on WA on sterilized twigs of apple (Malus sp.), Eucalyptus sp., Populus sp., or needles of Pinus sp. within 7-14 d) superficial, globose, mostly solitary or in aggregates of 2-4 and covered by mycelium. Conidia similar to those formed on the host, but shorter, broadly fusiform to ovoid and more regular in shape, occasionally 1-2 septate and light brown upon aging after discharge (15-) 16-20 × 5-6(-7) $\mu \mathrm{m}$ (average of 85 conidia $17.2 \times 5.5 \mu \mathrm{m}, 1 / \mathrm{w} 3.1$ ).

Specimens examined. USA. NEW YORK: Geneva, Ribes vulgare, 1911, J.G. Grossenbacher E B.M. Duggar (LECTOTYPE of teleomorph CUP-A-(F.Col. 3408)); Milton, Ribes vulgare, 1911, J.G. Grossenbacher E B.M. Duggar (CUP-A(F.Col. 3407)); Milton, Ribes vulgare, 1911, J.G. Grossenbacher E B B.M. Duggar (CUP-A-(F.Col. 3409)); Ithaca, Ribes sp., 2000, G. Hudler (HOLOTYPE of anamorph, PREM57368 culture CMW7772); Ithaca, Ribes sp., 2000, G. Hudler (PREM57369, culture CMW7773).

\section{DISCUSSION}

In this study, B. dothidea, B. ribis and B. parva are distinguished from each other and characterized based on morphological features. Epitype material is identified to complement neotype and syntype ma- 
terial of B. dothidea, the type species of Botryosphaer$i a$. Ex-type cultures from designated type specimens and other representative specimens have made it possible to confirm the identity of the groups of isolates that represent these taxa, through sequence data derived in this and other studies.

The type specimen of $B$. dothidea needed careful re-examination to clarify confusion regarding its name. In the original description by Mougeot (in Fries 1823, as Sphaeria dothidea), no specimen was designated as type but reference was made to a collection from fallen branches of Fraxinus sp. This material appears to be lost because the only material under this name from the Fries herbarium (which has been viewed as the type before; annotated by A.J.L. Phillips and J.A. von Arx with the sample) contains only material from what appears to be a Rosa sp. The holotype material from Fraxinus also could not be located in other herbaria that house collections of Mougeot. Given that no type material exists, a neotype was designated here for the remaining $S$. dothidea sample from the Fries collection (Greuter et al 2000; ICBN articles 9.6 and 9.11). This material, however, is immature as noted by other researchers (von Arx and Müller 1954, note by AJL Phillips with the sample) and thus does not bear characteristics that would make it possible to clearly define the name.

As part of the description of B. dothidea by Cesati and De Notaris (1863), two additional specimens, one from Fraxinus sp. collected by Koch, and one from Robinia pseudoacacia collected by Lasch, were cited. The type sheet bearing $B$. dothidea samples collected by Koch and Lasch also contains samples from Populus sp. (the inscription indicating the host species is not clear) and Fraxinus sp. collected by them. All materials also are immature, as is true for the collection from Fries' herbarium, or poor, and might even contain fruiting structures of more than one fungal species. This is not surprising because spore morphology was not a critical characteristic used in descriptions of different species by either Fries (1823) or Cesati and De Notaris (1863). Johnson (1992) also made reference to the immature and degraded state of the material but reported seeing one ascospore.

The type and other early specimens of B. dothidea mentioned in this study are not sufficient to characterize this species. This is due to the poor state of development of structures on specimens, poor preservation of characters and overlapping that exists in the morphological characteristics of Botryosphaeria spp. For these reasons, an epitype sample has been selected. Care has been taken with the selection of this epitype and the accompanying description to consider all aspects of the protologue, as well as to preserve the current usage of the name $B$. dothidea (Greuter et al 2000; ICBN article 9.7 and recommendation 9A). The epitype was selected from the same hosts and areas that the Cesati and De Notaris (1863) collections were made. Live cultures from this sample are deposited in culture collections (CMW, CBS).

We accept the synonymy of $B$. berengeriana and $B$. dothidea by von Arx and Müller (1954). In reviewing the original description, sketches and holotype material of $B$. berengeriana, and comparing these with the epitype of $B$. dothidea, no morphological or other reason could be found to resurrect $B$. berengeriana. The original description (De Notaris 1863) is very detailed and the ascomata on Rhamnus frangula, relatively well preserved. The original separation of this species from $B$. dothidea most likely was due to the variation in host and some variation in ascocarp morphology. However, we currently know that some Botryosphaeria spp. are not host specific. Furthermore, von Arx and Müller (1954) noted, and it is confirmed in this study, that variation can exist in the ascomatal and pycnidial morphology (e.g., size, aggregation and imbedding in tissue) of one Botryosphaeria sp. on different parts of one plant and between hosts.

Fusicoccum aesculi generally is accepted as the anamorph of B. dothidea sensu von Arx and Müller (1954). The separation of B. dothidea into at least two species, raises the question of the true identity of the anamorph of $B$. dothidea. The anamorph of the epitype of $B$. dothidea thus was studied in vivo and in vitro. The characteristics of the conidia and other morphological structures are in accordance with the amended description of $F$. aesculi (Crous and Palm 1999). The designation of $F$. aesculi as the anamorph of $B$. dothidea, as defined in this study, thus is accepted.

The type specimen of B. ribis is well preserved, providing ample material to define this taxon. However, no cultures are linked to this material. Freshly collected material from Ribes sp. in Ithaca, New York, the same host and area from which the lectotype of $B$. ribis was collected, contained only anamorph structures and conidia and thus could not be designated as epitype of the teleomorph (Greuter et al 2000; ICBN article 59.2). The structures on this material, however, morphologically were identical to anamorph structures and conidia on the lectotype specimen. The isolates from this freshly collected material thus are accepted as representing $B$. ribis.

Two cultural forms of $B$. ribis were described by Grossenbacher and Duggar (1911). The chromagena variant produced a reddish pigment when grown on starch media in diffuse daylight, while the achroma- 
gena variant did not. One isolate from Ribes sp. (CMW7054) was designated as a chromagena variant and produced a pigment similar to that described above, but not regularly, perhaps due to the age of the isolate as suggested by Witcher and Clayton (1963). No other B. ribis isolates used in this study produced such a pigment under artificial light or daylight and thus they all would be classified as achromagena variants. This characteristic initially was believed to relate to pathogenicity (Grossenbacher and Duggar 1911, Stevens and Jenkins 1924), but this notion later was rejected (Witcher and Clayton 1963). These designations no longer are used and are viewed as representative of intraspecific variation.

Grossenbacher and Duggar (1911) described a "simple or Macrophoma stylosporic form" and a "compound stylosporic or Dothiorella form" associated with B. ribis. These forms were separated based on whether the pycnidia were solitary, pycnidial and imbedded (on young succulent shoots) or botryose, stromatic and erumpent (on older more woody material). The former structures also were reported to have slightly smaller conidia. Re-examination of the material, however, revealed that the spores of these two morphological forms are of the same average dimension. Botryosphaeria spp. are known to display variation in the morphology of conidiomata on different parts or developmental stages of the same host (von Arx and Müller 1954, Phillips et al 2002). We, therefore, view these two forms described by Grossenbacher and Duggar (1911) as representing different characteristics of the same species.

The anamorph of $B$. ribis was not named in the description by Grossenbacher and Duggar (1911). These authors argued that the anamorph of B. ribis was not Dothiorella ribis (Fuckel) Sacc. or D. ribicola Ellis \& Barthol. but did not provide a name for it. The morphological and molecular data provided in this and other studies (Morgan-Jones and White 1987, Rayachhetry et al 1996, Denman et al 2000), however, show that the anamorph of $B$. ribis is a species of Fusicoccum. We have chosen to provide the name $F$. ribis for this element of the holomorph. Lectotype material of the teleomorph also contains anamorph structures. Freshly collected material, however, is designated here as holotype for the anamorph name, to allow characterization of living isolates and so preserve all features of this taxon. Although it might be argued that an anamorph name is not strictly necessary, the fungus most commonly is seen as the anamorph in the laboratory. We believe that having a name for this state will be useful. This is especially true because many apparently new species of Fusicoccum currently are being discovered and only the anamorph is known for them.
In addition to B. ribis, we have obtained isolates of B. obtusa (Diplodia anamorph) from Ribes sp. in New York. Grossenbacher and Duggar (1911) encountered a dark-spored sphaeropsis-like fungus on Ribes, which they did not study. It is possible, however, that these researchers inadvertently isolated this fungus as an endophyte because not all their cultures were from spores or conidia. Botryosphaeria spp. are known to occur commonly as endophytes in many woody plants (Fisher et al 1993, Smith et al 1996). It thus is possible that some of the variation in cultural morphology described in the experiments of Grossenbacher and Duggar (1911) could be due to the presence of a second species of Botryosphaeria, namely B. obtusa.

Sequence data for the three gene regions used in this study show clearly that isolates of $B$. ribis and $B$. parva, respectively, reside in two clades. In contrast, data from the ITS, mt-SSU-rDNA gene sequence and RAPD data (Smith and Stanosz 2001, Zhou and Stanosz 2001a) did not distinguish B. parva from B. ribis, and it was suggested that these species might be synonyms. Yet again, a study using Inter Simple Sequence Repeat (ISSR) markers separated these two species (Zhou et al 2001). Our data, based on a multiple gene genealogy, strongly support the view that $B$. ribis and B. parva are distinct and probably recently derived.

Some of the unique polymorphisms detected in the sequence data of this study, and that distinguish B. ribis from B. parva, are repetitive elements in the intron regions. Such elements can be highly polymorphic within species (Carbone et al 1999, Fisher et al 2000). Since the three isolates representing $B$. ribis all were collected from the same site and host (Ribes from New York), the variation that we observed at these sites might reflect the presence of a founder population. This is especially true given that preliminary data suggest that these fungi are nonoutcrossing (H van Geuns, B Slippers, and S Denman unpubl), and that Ribes spp. have been introduced into the New York area. Furthermore, there is also sequence variation among isolates in the $B$. parva clade. These results call for a study of a wider collection of isolates, using codominant markers to determine possible gene flow and boundaries between groups of isolates that represent these species.

The morphological description of B. parva (Pennycook and Samuels 1985) is indistinguishable from that of B. ribis by Grossenbacher and Duggar (1911) and Punithalingam and Holliday (1973), except that the conidia and ascospores in the former species are reportedly wider and slightly shorter. These differences were not evident in our study, and the characteristics overlapped between the species. Penny- 
cook and Samuels (1985), however, did not consider the synonymy of these species because they treated $B$. ribis as a synonym of $B$. dothidea sensu von Arx and Müller (1954). These authors and Punithalingam and Holliday (1973) refer to septation in older spores. Our observations show that the pattern of septation and discoloration in older, discharged conidia formed in culture is consistent with the separation of $B$. ribis and $B$. parva based on sequence data. Aging conidia of both species become one to two septate and light brown after being discharged from the pycnidium. Conidia of B. ribis, however, are commonly one-septate and dark walls are evenly spread. In contrast, conidia of B. parva are more regularly two septate, with conspicuously darker brown middle cells. However, care must be taken in making these observations because not all conidia darken and become septate, even after discharge and in cases where cultures are left to age 2 mo.

Isolates residing in the $B$. ribis/B. parva clade reportedly form microconidia or spermatia (Pennycook and Samuels 1985, Rayachhetry et al 1996). These structures are not common and were not observed in our study. Phillips et al (2002) also recently reported spermatia of similar dimensions to those described for B. ribis/B. parva, formed by some isolates of B. lutea. Spermatia have not been reported from B. dothidea. In our study, however, microconidia were formed in anamorph fruiting structures of $B$. dothidea from Ostrya sp. This characteristic appears to be insufficiently consistent to be useful in distinguishing between the B. ribis, B. parva and B. dothidea.

The Botryosphaeria spp. considered in this study resided in two major and well-resolved clades, based on the combined sequence datasets of the ITS rDNA, $\beta$ tubulin and EF1- $\alpha$. These clades correspond to the anamorph genera with hyaline conidia in Fusicoccum and those with dematiaceous conidia in Diplodia sensu lato. These two groups also have been identified in previous studies (Denman et al 2000, Zhou and Stanosz 2001a). Despite a report to the contrary (Zhou and Stanosz 2001b), the fusicoccum- and diplodia-like anamorph conidium phenotype, therefore, seem to be consistent with major evolutionary events in Botryosphaeria.

Based on the combined sequence datasets used in this study, B. rhodina (anamorph = Lasiodiplodia theobromae (Pat.) Griff. \& Maubl.) grouped with other species having Diplodia anamorphs. These combined and separately analyzed datasets also showed that this species groups separately within the larger Diplodia clade, in which B. obtusa, B. stevensii and B. quercuum group closely. The conidial morphology of B. rhodina is similar to that of other Diplodia spp., but conidia also are unique in having conspicuous longitudinal striations. Our data thus suggest that conidial striations are definitive at the species level and should not be used to distinguish genera within Botryosphaeria or its anamorphs.

Botryosphaeria dothidea, B. ribis and B. parva clearly can be distinguished based on morphological and DNA sequence data. However, when considering morphology, care should be taken to examine a sufficiently large number of samples to compensate for the fact that some characteristics overlap significantly. For in vitro studies, sporulating cultures should be allowed to age at least $3 \mathrm{wk}$ and preferably longer because septation of discharged, aged spores is useful in separating some species. Recently collected isolates should be used because cultures can lose their useful characteristics and ability to sporulate after repeated subculturing. We thus rely strongly on sequence data linked to morphologically defined groups to confirm their identity. For phylogenetic studies of closely related species such as B. ribis and $B$. parva, more than one gene region should be used. However, there is a preponderance of ITS rDNA sequence data for Botryosphaeria spp. in public databases and this appears to be sufficient to identify the major clades.

KEY TO B. DOTHIDEA, B. RIBIS, B. PARVA, AND B. LUTEA

Botryosphaeria lutea is included in the key because it is closely related and commonly encountered in comparison with the other species studied here (Jacobs and Rehner 1998, Zhou and Stanosz 2001a, Smith and Stanosz 2001, Phillips et al 2002). Data for $B$. lutea in this key are derived from Pennycook and Samuels (1985) and Phillips et al (2002) and were confirmed in this study. . . . . . . . . . .

1. Conidia in culture averaging $<18 \mu \mathrm{m}$ long, $1 / \mathrm{w} \pm 3$, colony on MEA or PDA thick felt of gray aerial mycelium ... . 2

1. Conidia in culture averaging $\geq 20 \mu \mathrm{m}$ long, $1 / \mathrm{w}>3$, colony on MEA or PDA appressed with only occasional tufts of gray to buff aerial mycelium ............ 3

2. Conidia 15-20 $\times 5-7 \mu \mathrm{m}$, becoming light brown and septate after discharge ................ ribis

2. Conidia $12-23 \times 4-6 \mu \mathrm{m}$, frequently becoming light brown and one to two septate with a darker brown middle cell after discharge ............. parva

3. Conidia fusiform to irregularly rod-shaped, $15-30 \times 5-8$ $\mu \mathrm{m}$ (average $22 \times 6$ ), 1/w 3-4, colony on MEA or PDA producing distinct yellow pigment after $3 \mathrm{~d}$, becoming dull brown to buff with age ............... lutea

3. Conidia narrowly fusiform, $19-30 \times 4-6 \mu \mathrm{m}$ (average 25 $\times 5), 1 / \mathrm{w} 3.5-6$, colonies on MEA or PDA not producing yellow pigment and becoming gray to black with age ...

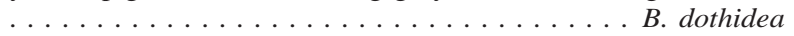

\section{ACKNOWLEDGMENTS}

We thank the National Research Foundation, Mellon Foundation, members of the Tree Pathology Co-operative Programme (TPCP) and the THRIP initiative of the Department of Trade and Industry (DTI), South Africa, for financial assistance. We also are most grateful to Prof. George Hudler, Dr. Orlando Petrini, Dr. Liliane Petrini, Ms. Neria 
Römer, Ms. Cristina Stinelli and Mr. Pierfranco Arrigoni for their tremendous effort in assisting us in collecting epitype and other specimens crucial to this study. Likewise, this study would not have been possible without the support of culture collections and herbaria worldwide (CUP, PDD, RO, S) that kindly supplied specimens and cultures.

\section{LITERATURE CITED}

Barr ME. 1972. Preliminary studies on the Dothideales in temperate North America. Contr Univ Mich Herb 9: 523-638.

Brown EA, Britton KO. 1986. Botryosphaeria diseases of apple and peach in the Southeastern United States. Plant Dis 70:480-484.

Carbone I, Anderson JB, Kohn LM. 1999. A method for designing primer sets for the speciation studies in filamentous ascomycetes. Mycologia 91:553-556.

Cesati V, De Notaris G. 1863. Schema di classificazione degli sferiacei italici aschigeri piu' o meno appartenenti al genere Sphaeria nell'antico significato attribuitoglide Persoon. Comment Soc Crittog Ital 1 4:177-240.

Crous PW, Palm ME. 1999. Reassessment of the anamorph genera Botryodiplodia, Dothiorella and Fusicoccum. Sydowia 52:167-175.

Denman S, Crous PW, Wingfield MJ. 1999. A taxonomic reassessment of Phyllachora proteae, a leaf pathogen of Proteaceae. Mycologia 91:510-516.

_ _ - Taylor JE, Kang JC, Pascoe I, Wingfield MJ. 2000. An overview of the taxonomic history of Botryosphaeria and a re-evaluation of its anamorphs based on morphology and ITS rDNA phylogeny. Stud Mycol 45: 129-140.

De Notaris G. 1863. Sferiacei Italici. Genova: Tipi del R.I. de' Sordo-Muti. pp. 82-84.

English H, Davis JR, DeVay JE. 1975. Relationship of Botryosphaeria dothidea and Hendersonula toruloidea to a canker disease of almond. Phytopathology 65:114-122.

Eriksson T. 1998. Autodecay ver. 4.0 (program distributed by the author). Department of Botany, Stockholm University, Stockholm.

Farris JS, Kallersjo M, Kluge AG, Bult C. 1995. Testing significance of incongruence. Cladistics 10:315-319.

Felsenstein J. 1985. Confidence intervals on phylogenetics: an approach using bootstrap. Evolution 39:783-791.

Fisher MC, Koenig G, White TJ, Taylor JW. 2000. A test for concordance between the multilocus genealogies of genes and microsatelites in the pathogenic fungus Coccidioides immitis. Mol Biol Evol 17:1164-1174.

Fisher PJ, Petrini O, Sutton BC. 1993. A comparative study of fungal endophytes in leaves, xylem and bark of Eucalyptus nitens in Australia and England. Sydowia 45:114.

Fries E. 1823. Systema Mycolgicum. 2(2):423-424.

Glass NL, Donaldson GC. 1995. Development of primer sets designed for use with the PCR to amplify conserved genes from filamentous Ascomycetes. Appl Environ Microbiol 61:1323-1330.

Greuter W, McNeill J, Barrie FR, Burdet HM, Demoulin V,
Filgueiras TS, Nicolson DH, Silva PC, Skog JE, Trehane P, Turland NJ, Hawksworth DL. 2000. International Code of Botanical Nomenclature (St. Louis). XVI International Botanical Congress, St. Louis, Missouri, JulAug 2000. Königstein, Germany: Koeltz Scientific Books. 389 p.

Grossenbacher JG, Duggar BM. 1911. A contribution to the life-history, parasitism, and biology of Botryosphaeria ribis. NY Agric Exp Station, Tech Bull 18:113-190.

Hillis DM, Huelsenbeck JP. 1992. Signal, noise, and reliability in molecular phylogenetic analyses. J Hered 83: 189-195.

Huelsenbeck JP, Bull JJ, Cunningham CW. 1996. Combining data in phylogenetic analysis. TREE 11:152-158.

Jacobs KA, Rehner SA. 1998. Comparison of cultural and morphological characters and ITS sequences in anamorphs of Botryosphaeria and related taxa. Mycologia 90:601-610.

Johnson GI. 1992. Biology and control of stem end rot pathogens of mango [Doctoral Thesis]. Queensland, Australia: University of Queensland. 265 p.

Maas JL, Uecker FA. 1984. Botryosphaeria dothidea cane canker of thornless blackberry. Plant Dis 68:720-726.

Morgan-Jones G, White JF Jr. 1987. Notes on Coelomycetes. II. Concerning the Fusicoccum anamorph of Botryosphaeria ribis. Mycotaxon 30:117-125.

O’Donnell K, Cigelnik L. 1997. Two divergent intragenomic rDNA ITS2 types within the monophyletic lineage of the fungus Fusarium are nonorthologous. Mol Phylogenet Evol 7:103-116.

Ogata T, Sano T, Harada Y. 2000. Botryosphaeria spp. isolated from apple and several deciduous fruit trees are divided into three groups based on the production of warts on twigs, size of conidia, and nucleotide sequences of nuclear ribosomal DNA ITS regions. Mycoscience 41:331-337.

Pennycook SR, Samuels GJ. 1985. Botryosphaeria and Fusicoccum species associated with ripe fruit rot of Actinidia deliciosa (Kiwifruit) in New Zealand. Mycotaxon 24: 445-458.

Phillips AJL, Fonseca F, Povoa V, Castilho R, Nolasco G. 2002. A reassessment of the anamorphic fungus Fusicoccum luteum and description of its teleomorph Botryosphaeria lutea sp. nov. Sydowia 54:59-77.

Punithalingam E, Holliday P. 1973. Botryosphaeria ribis. CMI descriptions of pathogenic fungi and bacteria, No. 395. Kew, Surrey, England: Commonwealth Mycological Institute. 2 p.

Putterill VA. 1919. A new apple tree canker. S Afr J Sci 16: 258-271.

Raeder U, Broda P. 1985. Rapid preparation of DNA from filamentous fungi. Lett Appl Microbiol 1:17-20.

Rayachhetry MB, Blakeslee GM, Webb RS, Kimbrough JW. 1996. Characteristics of the Fusicoccum anamorph of Botryosphaeria ribis, a potential biological control agent for Melaleuca quinquenervia in South Florida. Mycologia 88:239-248.

Rayner RW. 1970. A mycological colour chart. Kew, Surrey, UK: CMI and British Mycological Society. 34 p. 
Saccardo PA. 1877. Fungi Veneti novi vel critici. Michelia 1: $1-72$.

- 1882. Sylloge fungorum omnium hucusque cognitorum 1:456-466.

Sassa T, Ishizaki A, Nukina M, Ikeda M, Sugiyama T. 1998. Isolation and identification of new antifungal macrophorins E, F and $\mathrm{G}$ as malonyl meroterpenes from $\mathrm{Bo}$ tryosphaeria berengeriana. Biosci Biotech Bioch 62: 2260-2262.

Shoemaker RA. 1964. Conidial states of some Botryosphaeria species on Vitis and Quercus. Can J Bot 42:1297-1301.

Smith H, Kemp GHJ, Wingfield MJ. 1994. Canker and dieback of Eucalyptus in South Africa caused by Botryosphaeria dothidea. Plant Pathol 43:1031-1034.

— Wingfield MJ, Crous PW, Coutinho TA. 1996. Sphaeropsis sapinea and Botryosphaeria dothidea endophytic in Pinus spp. and Eucalyptus spp. in South Africa. S Afr J Bot 62:86-88.

— BD. 2001. Botryosphaeria eucalyptorum sp. nov., a new species in the B. dothidea-complex on Eucalyptus in South Africa. Mycologia 93:277-284.

Smith DR, Stanosz GR. 2001. Molecular and morphological differentiation of Botryosphaeria dothidea (anamorph Fusicoccum aesculi) from some other fungi with Fusicoccum anamorphs. Mycologia 93:505-515.

Spiers AG. 1977. Botryosphaeria dothidea infection of Salix species in New Zealand. Plant Dis Rep 61:664-667.

Stevens NE, Jenkins AE. 1924. Occurrence of the current cane blight fungus on other hosts. J Agric Res 27:837844.

Sutton BC. 1980. The Coelomycetes, Fungi inperfecti with pycnidia, acervuli and stromata. Kew, Surrey, England: Commonwealth Mycological Institute. 696 p.

Swofford DL. 1999. PAUP*. Phylogenetic analysis using parsimony (*and other methods). Version 4. Sunderland, Massachusetts: Sinauer Associates.
Taylor JW, Jacobson DJ, Kroken S, Kasuga T, Geiser DM, Hibbett DS, Fisher MC. 2000. Phylogenetic species recognition and species concepts in fungi. Fungal Genet Biol 31:21-32.

Trotter A. 1928. Sylloge fungorum omnium hucusque cognitorum 24(2):810-815.

White TJ, Bruns T, Lee S, Taylor J. 1990. Amplification and direct sequencing of fungal ribosomal RNA genes for phylogenetics. In: Innis MA, Gelfand DH, Snisky JJ, White TJ, eds. PCR protocols: a guide to methods and applications. San Diego: Academic Press. p 315-322.

Winter G. 1886. Ascomyceten: Gymnoasceen und Pyrenomyceten. Rabenh Krypt-Fl II (band 1) abth 2:800-803.

Witcher W, Clayton CN. 1963. Blueberry stem blight caused by Botryosphaeria dothidea (B. ribis). Phytopathology 42:521-525.

Zhou S, Smith DR, Stanosz GR. 2001. Differentiation of Botryosphaeria species and related anamorphic fungi using Inter Simple or Short Sequence Repeat (ISSR) fingerprinting. Mycol Res 105:919-926.

— Stanosz GR. 2001a. Relationships among Botryosphaeria species and associated anamorphic fungi inferred from the analyses of ITS and 5.8S rDNA sequences. Mycologia 93:516-527.

,$--2001 \mathrm{~b}$. Primers for amplification of $\mathrm{mt} \mathrm{SSU}$ rDNA, and a phylogenetic study of Botryosphaeria and associated anamorphic fungi. Mycol Res 105:10331044.

von Arx JA. Müller E. 1954. Die Gattungen der amerosporen Pyrenomyceten. Beitr Kryptogamenfl Schweiz 11(1):1-434.

-1 . 1975. A re-evaluation of the bitunicate Ascomycetes with keys to families and genera. Stud Mycol 9:1-159.

von Arx JA. 1987. Plant pathogenic fungi. Beheifte zur Nova Hedwigia 87:288p. 